J. of Korean Inst. of Resources Recycling

Vol. 21, No. 4, 2012, 53-59

研究論文

熔融 $\mathrm{Bi}-\mathbf{P b}-\mathrm{Sb}$ 系 合金의 酸化에 의한 $\mathbf{S b}$ 과 $\mathbf{P b}$ 除去 ${ }^{\dagger}$

金世宗・孫仁俊・中孫豪祥

慶北大學校 金屬新素材工學科

\title{
The Selective Removal of Sb and Pb from Molten Bi-Pb-Sb Alloy by Oxidation ${ }^{\dagger}$
}

\author{
Se-Jong Kim, In-Joon Son and ₹Ho-Sang Sohn
}

Dept. of Materials Science and Metallurgical Engineering, Kyungpook National University, Daegu 702-701, Korea

\section{요 약}

본 연구에서는 비철제련의 공정 부산물에서 얻어진 $\mathrm{Bi}-\mathrm{Pb}-\mathrm{Sb}$ 3원계 합금 용탕의 산화반응에 따른 $\mathrm{Sb}$ 과 $\mathrm{Pb}$ 의 제거거동에 대하여 조사하였다. $\mathrm{N}_{2}+\mathrm{O}_{2}$ 가스를 침지 노즐을 통해 $1173 \mathrm{~K}$ 의 합금 용탕 중에 취입하여 $\mathrm{Sb}$ 을 산화물과 금속상의 혼합물로 분리 회수할 수 있었다. 그리고 $923 \mathrm{~K}$ 의 $\mathrm{Bi}-\mathrm{Pb}$ 2원계 용탕에 $\mathrm{N}_{2}+\mathrm{O}_{2}$ 가스를 취입하면 $\mathrm{Pb}$ 가 산화되어 슬래그상으로 제거될 수 있으나, $\mathrm{Bi}$ 도 동 시에 산화되어 $\mathrm{Bi}$ 를 정제할 수 없었다.

주제어 : 비철제련, 부산물, 정련, 가스취입, 회수

\section{Abstract}

In this study, behaviors of removing $\mathrm{Sb}$ and $\mathrm{Pb}$ by oxidation of molten $\mathrm{Bi}-\mathrm{Pb}-\mathrm{Sb}$ alloy which is a by-product of non-ferrous smelting process was investigated. The molten alloy was oxidized at $1173 \mathrm{~K}$ by bubbling $\mathrm{N}_{2}+\mathrm{O}_{2}$ gas through a submerged nozzle. The $\mathrm{Sb}$ was removed and recovered as mixed phase of $\mathrm{Sb}_{2} \mathrm{O}_{3}$ and metal $\mathrm{Sb}$. In the case of bubbling $\mathrm{N}_{2}+\mathrm{O}_{2}$ gas into molten $\mathrm{Bi}-\mathrm{Pb}$ alloy at $923 \mathrm{~K}, \mathrm{~Pb}$ was oxidized and removed to slag. But $\mathrm{Bi}$ could not be refined due to simultaneous oxidization of $\mathrm{Bi}$ with $\mathrm{Pb}$.

Key words : Non-ferrous smelting, By-product, Refining, Gas bubbling, Recovery

\section{1. 서}

제련공정 부산물의 리싸이클링은 자원확보는 물론 환 경문제, 에너지문제 등의 관점에서 매우 중요한 위치를 차지하게 되었다. 그러나 경제성이나 기술적인 문제 등 으로 인하여 충분히 대응하여 오지 못한 것이 사실이다. 최근 희유금속의 자원확보 관점에서 도시광산에 대하여 많은 관심을 가지고 있으나, ${ }^{1)}$ 우선적으로 공정 부산물 중에 함유되어 있는 유가금속 회수기술의 개발이 시급 한 실정이다. 특히 비철금속 광물 중에는 목적금속 이 외에도 미량이지만 여러 종류의 희유금속이 함유되어

†2012년 5월 21일 접수, 2012년 6월 22일 1차수정
2012년 7월 9일 수리
†E-mail: sohn@knu.ac.kr

있으므로 제련소의 경쟁력 확보는 물론 자원확보 관점 에서 이러한 희유금속의 회수는 필수적이라 할 수 있다. 국내 $\mathrm{A}$ 사의 경우 제련공정으로부터 9 종의 희유금속을 회수하고 있으며, $\mathrm{B}$ 사의 경우 17 종의 희유금속을 회수 하고 있다.1) 일본의 Kosaka제련소에서는 동제련 공정 부산물을 원료로 사용하는 연제련 공정에서 전기연, 비 스무트, 삼산화안티몬 등을 생산하고 있다. ${ }^{2)}$ 그리고 Mitsui금속의 Takehara제련소3)에서는 연 공정 슬래그, 축전지 스크랩 등을 원료로 사용하여 조연을 제조하고, 부산물로 주석과 삼산화 안티몬 등을 회수하고 있다.

이러한 동제련, 아연제련 그리고 연제련의 공정에서 발생하는 부산물을 회수하는 공정은 부산물의 종류에 따라 여러 방법이 실용화되어 있다. Harris법은 ${ }^{4)}$ 조연 (crude lead) 중에 알칼리 혼합물 $\left(\mathrm{NaOH}, \mathrm{NaNO}_{3}\right.$ 등)을 
첨가하여 불순물인 $\mathrm{As}, \mathrm{Sb}, \mathrm{Sn}$ 등을 산화시켜 제거하 거나 분리하는 방법이다. 특히 이 공정에서 발생하는 주 석 슬래그를 온수로 침출하여 전해채취하면 $99.5 \%$ 이 상의 $\mathrm{Sn}$ 을 회수 할 수 있다. 그리고 조연 중의 $\mathrm{Bi}$ 는 제거가 곤란한 것으로 알려져 있으나, Kroll-Betterton법 에서는 $\mathrm{Bi}$ 를 함유하는 용융 $\mathrm{Pb}$ 에 $\mathrm{Ca}$ 를 첨가하여 $\mathrm{Bi}_{2} \mathrm{Ca}_{3}$ (융점 $1201 \mathrm{~K}$ )의 형태로 $\mathrm{Bi}$ 를 제거한다. 특히 $\mathrm{Mg}$ 은 단독으로는 용융 $\mathrm{Pb}$ 로의 용해도가 크고 효과가 적으나 $\mathrm{Ca}$ 과 함께 첨가하면 $\mathrm{Bi}_{2} \mathrm{CaMg}_{2}$ (융점 $1333 \mathrm{~K}$ ) 로 나타내는 고융점 화합물을 생성하여 용해도를 감소 시켜 $\mathrm{Ca}$ 단독의 경우보다 탈 $\mathrm{Bi}$ 능력을 향상시키는 것 이 가능한 것으로 알려져 있다.5)

한편, 연 등의 전해시에 양극 슬라임(slime) 중에는 $\mathrm{Sb}, \mathrm{Bi}, \mathrm{Au}, \mathrm{Ag}$ 등이 함유되어 있으므로 이를 전기로 중에서 환원하여 금속으로 만들어 처리하기도 한다. 특 히 제련공정에 따라서 환원된 금속은 $\mathrm{Bi}, \mathrm{Pb}, \mathrm{Sb}$ 의 3 원계 합금으로 만들어지는 경우가 있다. 이 합금 중에 산소가스를 취입하게 되면 $\mathrm{Sb}, \mathrm{Pb}, \mathrm{Bi}$ 순으로 산소와의 친화력이 높기 때문에 우선적으로 $\mathrm{Sb}$ 을 산화시킬 수 있 다. 그러나 상기한 Kroll-Betterton법은 $\mathrm{Bi}$ 를 불순물로서 제거하는 방법이며, $\mathrm{Bi}$ 중의 $\mathrm{Pb}$ 를 불순물로 제거하는 방법은 잘 알려져 있지 않다. 따라서 본 연구에서는 비 철 제련공정 부산물을 환원하여 생성되는 $\mathrm{Bi}-\mathrm{Pb}-\mathrm{Sb}$ 3원 계 합금의 산화반응에 따른 $\mathrm{Sb}$ 과 $\mathrm{Pb}$ 의 제거거동에 대 하여 정량적으로 조사하였다.

\section{2. 실험 방법}

본 연구에 사용된 실험장치의 개략도를 Fig. 1에 나타내 었다. 시료의 용융은 고주파유도 용해로 $(20 \mathrm{~kW}, 40 \mathrm{kHz})$ 를 이용하였고, 유도코일 내에 석영관(내경 $=110 \mathrm{~mm}$, 길 이 $=500 \mathrm{~mm}$ )을 설치하고, 석영관 상부와 하부에 플랜 지를 장착하여 로 내 분위기를 조절할 수 있도록 하였 다. 석영관 내에 발열용 흑연 도가니(외경 $=90 \mathrm{~mm}$, 내 경 $=70 \mathrm{~mm}$, 길이 $=150 \mathrm{~mm}$ )를 설치하고, 흑연 도가니 의 외부를 내화포로 감싸서 방열을 방지하였다. 그리고 흑연 도가니 내에 시료를 장입한 고순도 $\mathrm{Al}_{2} \mathrm{O}_{3}$ 제 도가 니(내경 $=44 \mathrm{~mm}$, 길이 $=100 \mathrm{~mm}$ )를 설치하였다. 로 내 온도 조절용 열전대(R-type, Pt/Pt-13\%Rh)는 상부에서 흑연 도가니와 $\mathrm{Al}_{2} \mathrm{O}_{3}$ 도가니 사이에 삽입하고, $\mathrm{PID}$ 온 도제어장치를 이용하여 $\pm 2 \mathrm{~K}$ 의 범위에서 반응온도를 제 어하였다. 석영관 하부로부터 $\mathrm{N}_{2}$ 가스를 불어넣어 불활 성 분위기를 유지하였으며, 상부 플렌지에는 $\mathrm{N}_{2}+\mathrm{O}_{2}$ 혼

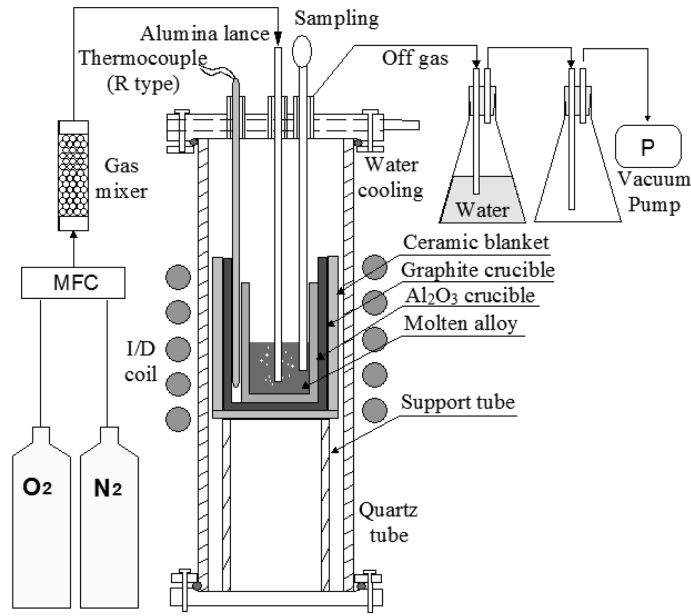

Fig. 1. Experimental apparatus.

합가스 취입을 위한 알루미나제 랜스(외경 $=6 \mathrm{~mm}$, 내 경 $=4 \mathrm{~mm})$ 투입구, 열전대 투입구, 시료채취를 위한 석 영관 $($ 외경 $=6 \mathrm{~mm}$, 내경 $=4 \mathrm{~mm}$ ) 투입구를 설치하였다. 그리고 필요에 따라서는 그림에서와 같이 배기되는 가 스를 진공펌프를 이용하여 물이 들어있는 삼각 플라스 크로 유도하여 휘발되는 물질을 회수하였다.

실험은 $400 \mathrm{~g}$ 의 $\mathrm{Bi}-30$ mass $\% \mathrm{~Pb}-20$ mass\%Sb의 3 원계 합금을 $\mathrm{Al}_{2} \mathrm{O}_{3}$ 도가니에 장입하고 $\mathrm{N}_{2}$ 가스 분위기 하에서 $923 \mathrm{~K}$ 와 $1173 \mathrm{~K}$ 까지 승온하였다. 승온이 완료된 후, 알루미나제 랜스를 알루미나 도가니 바닥에서 $1 \mathrm{~cm}$ 위까지 용탕 내에 침지하고 일정 수준의 산소 분압( 0.2 , $0.4 \mathrm{~atm})$ 으로 $\mathrm{N}_{2}+\mathrm{O}_{2}$ 혼합가스를 취입하였다. 혼합가스 의 유량은 MFC(Mass flow controller, MKS type 247)를 이용하여 제어하였다. 이후에 일정시간 간격으 로 시료를 채취하였다. 일부 실험에서는 시료를 채취하 지 않고 일정시간 동안 반응시킨 후 혼합가스 취입을 종료하고 냉각 후 시료의 무게변화를 측정하였다. 반응 초기에 산화되어 생성되는 $\mathrm{Sb}$ 산화물은 상기한 바와 같이 물이 들어있는 삼각 플라스크로 유도하여 포집하였다. 또 한, 1 차적으로 $\mathrm{Sb}$ 을 산화물로서 휘발 - 제거한 후, 계속 하여 $\mathrm{N}_{2}+\mathrm{O}_{2}$ 혼합가스를 취입하여 $\mathrm{Pb}$ 를 슬래그 상으로 제거하였다. 그리고 일부 실험에서는 $\mathrm{Pb}$ 의 산화거동을 조사하기 위해 $480 \mathrm{~g}$ 의 Bi- 37.5 mass\% $\%$ 의 2원계 합 금 용탕 내에 $\mathrm{N}_{2}+\mathrm{O}_{2}$ 혼합가스를 취입하며, 일정시간 간격으로 시료를 채취하였다.

포집한 $\mathrm{Sb}$ 산화물이나 슬래그는 $\mathrm{X}$-선 회절분석기 (Philips, CubiX)와 형광X-선 분석기(Oxford, XMET5100)를 
이용하여 분석하였고, 금속성분은 유도결합플라즈마 원 자방출 분광 광도계(ICP spectrophotometer, Perkin Elmer, Optima $7300 \mathrm{DV})$ 를 이용하여 분석하였다.

\section{3. 실험 결과 및 고찰}

\section{1. $\mathrm{Bi}-\mathrm{Pb}-\mathrm{Sb} 3$ 원계의 산화 거동}

본 연구의 온도범위에서 $\mathrm{Bi}, \mathrm{Pb}, \mathrm{Sb}$ 의 온도에 따른 깁 스 자유에너지 변화를 식(1) (4)에 나타내었으며, Fig. 2 에는 온도에 따른 깁스 자유에너지 변화를 계산한 결과 를 나타내었다.

$$
\begin{aligned}
& \frac{4}{3} \mathrm{Bi}(\mathrm{l})+\mathrm{O}_{2}(\mathrm{~g})=\frac{2}{3} \mathrm{Bi}_{2} \mathrm{O}_{3}(\mathrm{~s}, \mathrm{l}) \\
& \Delta G^{0}=-390,740+193.99 T(\mathrm{~J} / \mathrm{mol}),(545 \sim 1098 \mathrm{~K}) \\
& \Delta G^{0}=-314,130+123.10 T(\mathrm{~J} / \mathrm{mol}),(1098 \sim 1835 \mathrm{~K}) \\
& 2 \mathrm{~Pb}(\mathrm{l})+\mathrm{O}_{2}(\mathrm{~g})=2 \mathrm{PbO}(\mathrm{s}, \mathrm{l}), \\
& \Delta G^{0}=-439,340+200.40 T(\mathrm{~J} / \mathrm{mol}),(601 \sim 1159 \mathrm{~K}) \\
& \Delta G^{0}=-368,880+139.58 T(\mathrm{~J} / \mathrm{mol}),(1159 \sim 1897 \mathrm{~K}) \\
& \frac{4}{3} \mathrm{Sb}(\mathrm{s})+\mathrm{O}_{2}(\mathrm{~g})=\frac{2}{3} \mathrm{Bi}_{2} \mathrm{O}_{3}(\mathrm{~s}), \\
& \Delta G^{0}=-469,720+177.50 T(\mathrm{~J} / \mathrm{mol}),(298 \sim 904 \mathrm{~K}) \\
& \frac{4}{3} \mathrm{Sb}(\mathrm{l})+\mathrm{O}_{2}(\mathrm{~g})=\frac{1}{3} \mathrm{Sb}_{4} \mathrm{O}_{6}(\mathrm{~g}), \\
& \Delta G^{0}=-430,150+144.50 T(\mathrm{~J} / \mathrm{mol}),(928 \sim 1858 \mathrm{~K})
\end{aligned}
$$

Fig. 2에서 알 수 있는 바와 같이 $\mathrm{Sb}>\mathrm{Pb}>\mathrm{Bi}$ 순으로 산소와의 친화력이 높기 때문에 3 원계 합금용탕에 산소 가스가 취입되면 우선적으로 $\mathrm{Sb}$ 이 산화되고 뒤이어 $\mathrm{Pb}$ 가 산화될 것이다.

식(5)와 식(6)에는 각각 $\mathrm{Sb}_{4} \mathrm{O}_{6}$ 와 의 온도에 따른 증 기압을 나타내었다. $\left.{ }^{6}\right)$

$$
\begin{aligned}
& \mathrm{Sb}_{4} \mathrm{O}_{6}: \log P(\mathrm{mmHg})= \\
& -3,900 / \mathrm{T}+5.137,(T=929 \mathrm{~K} \sim 1073 \mathrm{~K}) \\
& \mathrm{Sb}_{x}: \log P(\mathrm{mmHg})=-6,500 / \mathrm{T}+6.37,(T=904 \mathrm{~K} \sim \text { b.p. })
\end{aligned}
$$

식(6)에서 $\mathrm{Sb}_{x}$ 는 $\mathrm{Sb}$ 와 $\mathrm{Sb}_{2}$ 를 나타낸다. $1173 \mathrm{~K}$ 에서 $\mathrm{Sb}_{4} \mathrm{O}_{6}$ 와 $\mathrm{Sb}_{x}$ 의 증기압은 각각 $0.085 \mathrm{~atm}$ 과 $0.0089 \mathrm{~atm}$ 이므로 $\mathrm{Sb}$ 은 산화되면 비교적 쉽게 휘발제거 되어 회 수할 수 있을 것으로 생각된다.

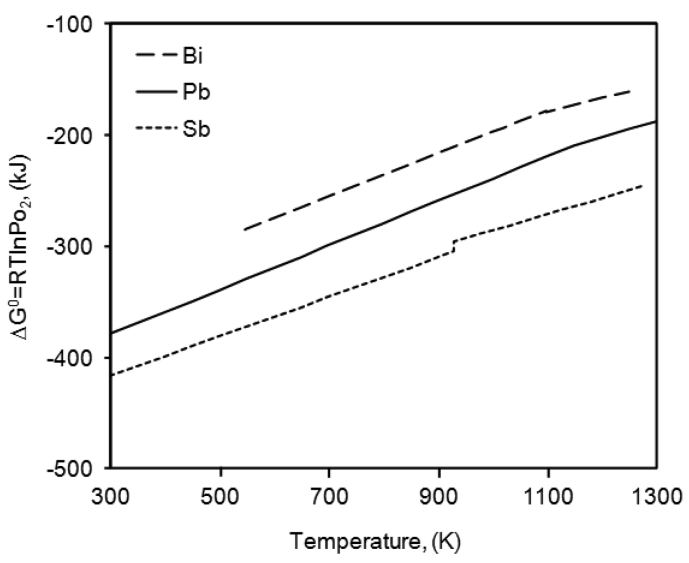

Fig. 2. Plots of Gibbs free energy change of oxidation of Bi, $\mathrm{Pb}$ and $\mathrm{Sb}$.

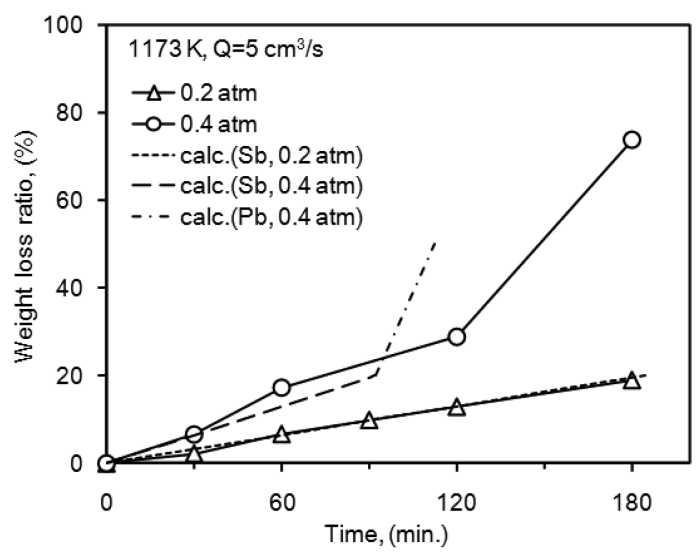

Fig. 3. Effect of oxygen partial pressure of $\mathrm{N}_{2}+\mathrm{O}_{2}$ gas on the weight loss ratio of $\mathrm{Bi}-30$ mass $\% \mathrm{~Pb}-20$ mass $\% \mathrm{Sb}$ alloys.

Fig. 3에는 $1173 \mathrm{~K}$ 에서 $400 \mathrm{~g}$ 의 Bi-30 mass $\% \mathrm{~Pb}-20$ mass $\% \mathrm{Sb}$ 조성의 3원계 합금용탕 내에 $\mathrm{N}_{2}+\mathrm{O}_{2}$ 혼합가 스를 $5 \mathrm{~cm}^{3} / \mathrm{s}$ 의 유량으로 일정 시간동안 취입한 경우, 산소분압에 따른 시료의 무게감량 비율을 나타내었다. 산소분압이 증가함에 따라 시료의 무게감량 비율이 직 선적으로 증가하였다. 용탕 중에 $\mathrm{N}_{2}+\mathrm{O}_{2}$ 혼합가스를 취 입하게 되면, 산소분압이 $0.2 \mathrm{~atm}$ 인 경우 약 180 분, $0.4 \mathrm{~atm}$ 인 경우에는 약 90 분만에 시료 중의 $\mathrm{Sb}$ 이 전 량 산화되어 $\mathrm{Sb}_{4} \mathrm{O}_{6}$ 상태로 제거될 수 있으며, 그림 중 에 이러한 계산 결과를 각각의 점선으로 나타내었다. 산 소분압이 $0.2 \mathrm{~atm}$ 인 경우에는 이러한 계산결과와 매우 잘 일치하여 $\mathrm{Sb}$ 의 제거에 대한 산소이용 효율은 거의 $100 \%$ 수준으로 나타났다. 그러나 산소분압이 $0.4 \mathrm{~atm}$ 인 


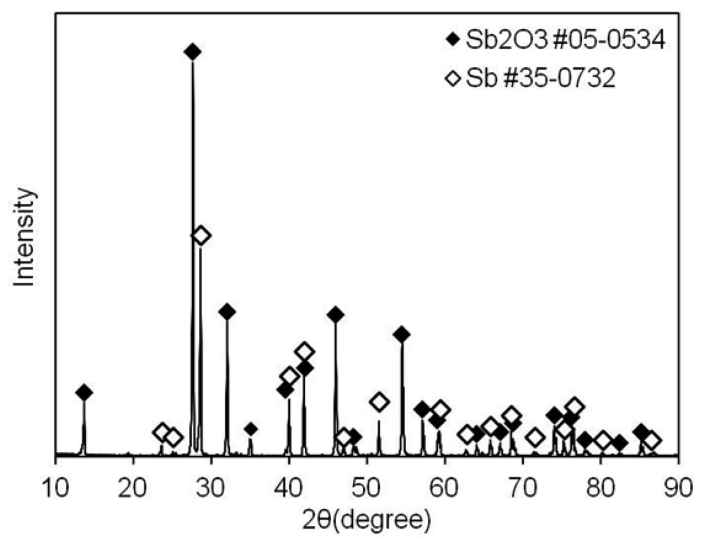

Fig. 4. $\mathrm{XRD}$ pattern of evaporated particles after oxidized at $1173 \mathrm{~K}$ by bubbling $\mathrm{N}_{2}+\mathrm{O}_{2}$ gas $\left(\mathrm{P}_{\mathrm{O} 2}=0.2 \mathrm{~atm}\right.$, $\left.\mathrm{Q}=5 \mathrm{~cm}^{3} / \mathrm{s}\right)$.

경우 일정시간이 경과한 후에는 이론적인 계산값 보다 약간 많은 비율로 무게 감량이 일어났다. 용탕 중에 취입 된 산소가스 $1 \mathrm{~mol}$ 은 식(2)와 (3)에 따라 각각 $\mathrm{Pb} 2 \mathrm{~mol}$ 과 $\mathrm{Sb} 4 / 3 \mathrm{~mol}$ 과 반응한다. 따라서 산소분압이 높은 경 우에 $\mathrm{Sb}$ 제거의 이론값보다 높은 비율로 무게가 감소된 것은 산소가 용탕 중의 $\mathrm{Sb}$ 과 반응함과 동시에 $\mathrm{Pb}$ 와도 반응하였기 때문으로 생각된다. 그리고 $\mathrm{Sb}$ 이 제거된 후 에 계속하여 혼합가스를 취입하게 되면 $\mathrm{Pb}$ 가 산화되어 슬래그로 제거될 수 있으며, 약 110 분이 경과하면 $\mathrm{Pb}$ 가 완전히 제거되어 슬래그로 분리되어야 하지만, 그림에서 와 같이 $\mathrm{Pb}$ 제거의 이론적인 값보다 낮은 제거속도를 보 였다. 이러한 결과는 취입된 산소 $1 \mathrm{~mol}$ 은 식(1)에 따라 $\mathrm{Bi} 4 / 3 \mathrm{~mol}$ 과 반응하므로, 취입된 산소가 $\mathrm{Pb}$ 의 산화와 동시에 $\mathrm{Bi}$ 의 산화에도 소비되었기 때문으로 생각된다.

Fig. 4에는 $1173 \mathrm{~K}$ 에서 3 원계 합금용탕 내에 산소분 압이 $0.2 \mathrm{~atm}$ 인 $\mathrm{N}_{2}+\mathrm{O}_{2}$ 혼합가스를 $5 \mathrm{~cm}^{3} / \mathrm{s}$ 로 취입하였 을 때, 용탕으로부터 증발되는 물질을 Fig. 1의 실험장 치에 나타낸바와 같이 진공 펌프를 이용하여 물이 들어 있는 삼각플라스크로 유도하여 포집하고 건조한 후 X선 회절 분석한 결과를 나타내었다. 3 원계 시료였음에도 불구하고 포집된 물질에서는 산화물인 $\mathrm{Sb}_{2} \mathrm{O}_{3}$ (JCPDS \#05-0534)와 금속 Sb(JCPDS \#35-0732)이 검출되었다. 상기한 바와 같이 $1173 \mathrm{~K}$ 에서 $\mathrm{Sb}_{x}$ 의 증기압은 $0.0089 \mathrm{~atm}$ 으로 매우 낮은 값이지만, 장시간 동안 혼합가스가 취 입되면서 일부 금속상의 $\mathrm{Sb}$ 이 증발한 것으로 생각된다. 따라서 $\mathrm{Bi}-\mathrm{Pb}-\mathrm{Sb}$ 3원계 합금 용탕 중에 산소가스를 취 입하는 것에 의해 $\mathrm{Sb}$ 만 산화물과 일부 금속상의 혼합

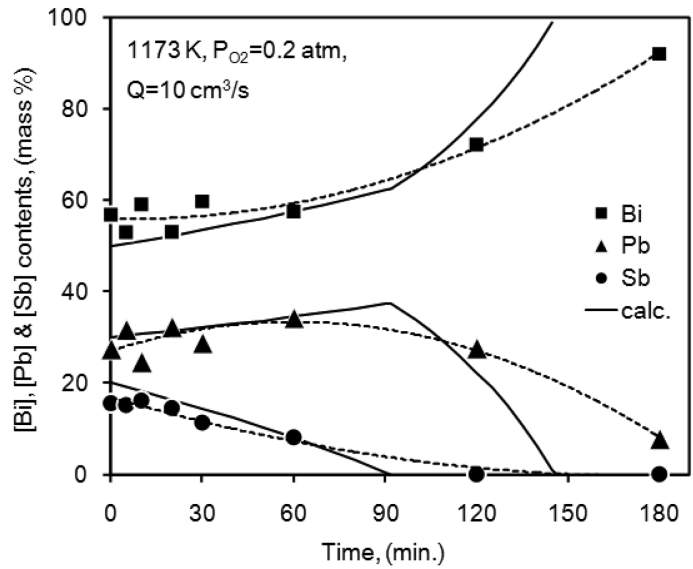

Fig. 5. Variations of $[\mathrm{Bi}],[\mathrm{Pb}]$ and $[\mathrm{Sb}]$ contents in ternary alloy with reaction time.

물로서 분리하여 회수할 수 있다는 것을 알 수 있다.

Fig. 5 에는 $1173 \mathrm{~K}$ 의 3 원계 합금용탕 중에 산소분압 이 $0.2 \mathrm{~atm}$ 인 $\mathrm{N}_{2}+\mathrm{O}_{2}$ 혼합가스를 $10 \mathrm{~cm}^{3} / \mathrm{s}$ 로 취입한 경 우, 반응시간에 따른 용탕 내의 조성 변화를 나타내었 다. 그림 중의 실선은 식(2)와 식(3)에 따라 $\mathrm{Sb}$ 과 $\mathrm{Pb}$ 의 제거에 따른 이론적 조성변화를 계산한 결과이다. 분석 값에 많은 편차가 있으나, 반응 시간이 증가함에 따라 $\mathrm{Sb}$ 은 산화 휘발되어 농도가 감소하기 시작하였고, 약 120 분이 경과하면 거의 대부분이 제거되었으며, 이론적 인 $\mathrm{Sb}$ 의 제거 거동과 유사한 경향을 나타내었다. 그리 고 $\mathrm{Sb}$ 의 제거에 따라 편차는 심하지만 $\mathrm{Bi}$ 와 $\mathrm{Pb}$ 의 농 도가 서서히 증가하는 경향을 나타내었으며, $50 \%$ 이상 의 $\mathrm{Sb}$ 이 제거된 60 분 이후부터는 $\mathrm{Pb}$ 의 농도가 감소하 기 시작하였고, $\mathrm{Bi}$ 의 농도는 계속하여 증가하였다. 이것 은 취입된 산소에 의해서 $\mathrm{Pb}$ 가 산화되어 슬래그상으로 제거되기 때문인 것으로 생각된다. 그러나 이론적으로 는 $\mathrm{Sb}$ 이 제거된 후, 취입된 산소에 의한 $\mathrm{Pb}$ 의 제거시 간은 146 분이지만, 180 분까지 산소를 취입하여도 약 $7.8 \mathrm{mass} \%$ 의 $\mathrm{Pb}$ 가 남아 있었다. 이것은 $\mathrm{Pb}$ 의 산화와 동시에 $\mathrm{Bi}$ 의 산화가 일어났나는 것을 의미한다.

\section{2. $\mathrm{Bi}-\mathrm{Pb} 2$ 원계 합금의 산화거동}

Fig. 6에는 Bi-30 mass\%Pb-20 mass\%Sb 3원계 합 금 중 $\mathrm{Sb}$ 이 $100 \%$ 제거된 것으로 가정하여 제조한 $\mathrm{Bi}-$ $37.5 \mathrm{mass} \% \mathrm{~Pb}$ 2원계의 $923 \mathrm{~K}$ 용탕 중에 산소분압 $0.2 \mathrm{~atm}$ 의 $\mathrm{N}_{2}+\mathrm{O}_{2}$ 혼합가스를 $10 \mathrm{~cm}^{3} / \mathrm{s}$ 로 취입한 경우 반응시간에 따른 용탕 내의 조성변화를 나타내었다. 그 


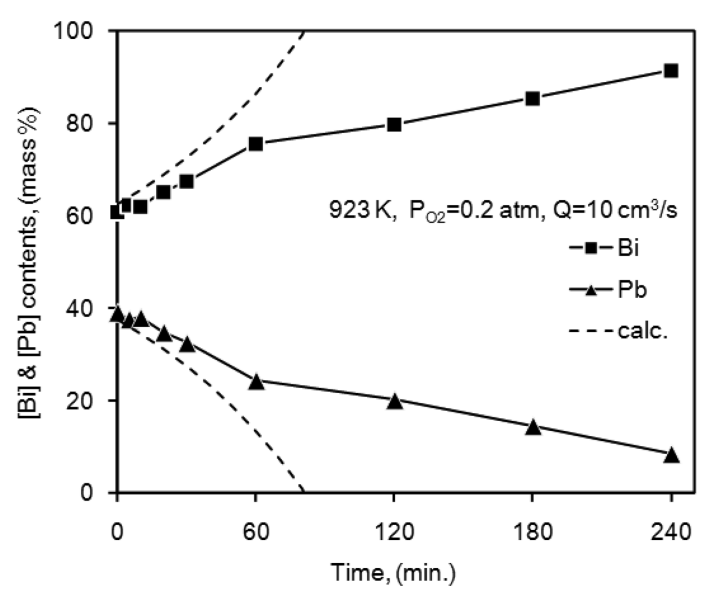

Fig. 6. Variations of $[\mathrm{Bi}]$ and $[\mathrm{Pb}]$ contents in binary alloy with reaction time.

림 중의 점선은 식(2)에 따라 취입된 산소가 $\mathrm{Pb}$ 와만 반응 하여 슬래그로 제거된 것으로 가정하여 계산한 결과이다. 혼합가스가 취입되면 곧바로 $\mathrm{Pb}$ 는 감소하기 시작하였으 며, $\mathrm{Bi}$ 는 증가하기 시작하였다. 그리고 반응초기에는 이론 적인 $\mathrm{Pb}$ 의 제거거동과 유사한 경향을 나타내었다. 그러나 60 분이 경과하면서 $\mathrm{Pb}$ 의 농도가 약 $25 \mathrm{mass} \%$ 이하가 되면 $\mathrm{Pb}$ 의 제거속도가 감소하고, $\mathrm{Bi}$ 의 증가속도도 감소 하여 이론적인 계산결과와는 많은 차이를 나타내었다. 그림에 점선으로 나타낸바와 같이 이론적으로는 81 분이 경과하면 $\mathrm{Pb}$ 가 완전히 제거되어야 하지만 240 분까지 혼 합 가스를 취입하여도 $8.5 \mathrm{mass} \%$ 의 $\mathrm{Pb}$ 가 잔류하였다. 따라서 취입된 산소는 Fig. 3과 Fig. 5에서 설명한 바 와 같이 $\mathrm{Pb}$ 뿐만 아니라 $\mathrm{Bi}$ 의 산화에도 소비되는 것으 로 생각된다.

Fig. 7에는 Fig. 6의 조건에서 생성된 슬래그의 외관 형상과 X-선 회절 분석 결과를 나타내었다. 슬래그는 황색의 $\mathrm{PbO}\left(\mathrm{JCPDS}\right.$ \#35-1482)와 $\mathrm{Bi}_{1.23} \mathrm{~Pb}_{0.77} \mathrm{O}_{2.62}(\mathrm{JCPDS}$ \#45-0291)의 복합 산화물로 나타났다. 따라서 산소가 함 유된 혼합가스를 $\mathrm{Bi}-\mathrm{Pb}$ 2원계 합금용탕 중에 취입하면 열역학적으로는 $\mathrm{Pb}$ 의 우선 산화만 일어나야 하지만 $\mathrm{Pb}$ 의 산화와 동시에 $\mathrm{Bi}$ 의 일부도 산화되어 $\mathrm{Bi}_{1.23} \mathrm{~Pb}_{0.77} \mathrm{O}_{2.62}$ 와 같은 $\mathrm{Bi}-\mathrm{Pb}$ 의 복합 산화물이 생성된다는 것을 나타낸다. 그리고 Fig. 5에서 설명한 3원계 합금용탕에서 $\mathrm{Sb}$ 이 산 화되어 휘발 제거된 후에 계속하여 혼합가스를 취입한 경우 잔류하는 금속상의 양이 예상보다 적게 나온 것도 산소에 의해서 $\mathrm{Bi}$ 의 일부가 $\mathrm{Pb}$ 와 동시에 산화되어 슬 래그상으로 제거되었기 때문으로 생각된다.

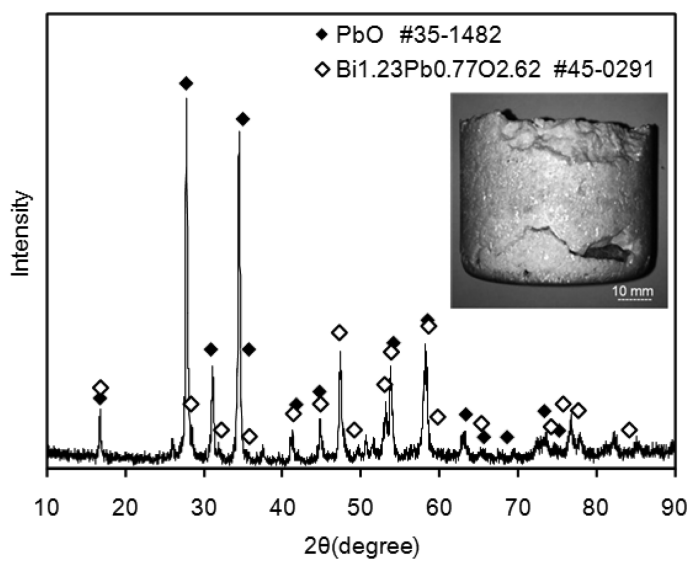

Fig. 7. XRD pattern and photograph of slag after oxidized at $923 \mathrm{~K}$ by bubbling $\mathrm{N}_{2}+\mathrm{O}_{2}$ gas $\left(\mathrm{P}_{\mathrm{O} 2}=0.2 \mathrm{~atm}\right.$, $\mathrm{Q}=10 \mathrm{~cm}^{3} / \mathrm{s}$ ).

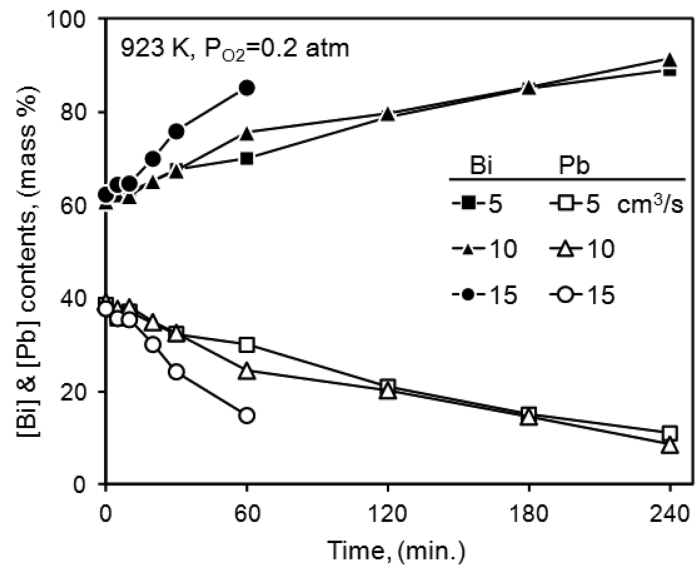

Fig. 8. Variations of $[\mathrm{Bi}]$ and $[\mathrm{Pb}]$ contents in binary alloys with the mixed gas flow rates.

Fig. 8에는 $923 \mathrm{~K}$ 의 $\mathrm{Bi}-37.5$ mass\% $\% \mathrm{~Pb}$ 2원계 용탕 중에 산소분압 $0.2 \mathrm{~atm}$ 의 $\mathrm{N}_{2}+\mathrm{O}_{2}$ 혼합 가스를 취입한 경우 가스유량에 따른 용탕의 성분 변화를 나타내었다. Fig. 6에서 설명한 바와 같이 시간의 경과에 따라 $\mathrm{Pb}$ 는 감소하고 $\mathrm{Bi}$ 는 증가하는 경향을 나타내었다. 그리고 저 유량에서는 큰 차이가 없으나 가스유량이 $15 \mathrm{~cm}^{3} / \mathrm{s}$ 로 증가하면 $\mathrm{Pb}$ 의 감소속도와 $\mathrm{Bi}$ 의 증가속도가 향상되었 지만, Fig. 6에서와 같이 반응 후반기로 가면서 $\mathrm{Pb}$ 의 제거속도와 $\mathrm{Bi}$ 의 증가속도가 감소하는 경항을 나타내었 다. 그리고 용탕 중의 $\mathrm{Pb}$ 가 $\mathrm{PbO}$ 로 산화되는데 필요한 량보다 많은 량의 산소가 취입되었지만, 금속상 중의 $\mathrm{Pb}$ 는 최저 $8.5 \mathrm{mass} \%$ 를 나타내었다. 그리고 $15 \mathrm{~cm}^{3} / \mathrm{s}$ 
로 취입한 경우에는 슬래그 생성량이 과다하여 60 분 이 후에는 더 이상 시료를 채취하기 곤란할 정도가 되었다. 이러한 현상은 생성된 슬래그가 고상으로 존재하고, Fig. 7에 나타낸 바와 같이 $\mathrm{Bi}$ 의 일부도 산화되어 잔류 하는 용탕의 양이 줄어들었기 때문으로 생각된다.

\section{3. $\mathrm{Pb}$ 산화제거의 열역학적 고찰}

$923 \mathrm{~K}$ 에서 식(1)로부터 계산한 $\mathrm{Bi}$ 산화의 평형산소 분압은 $1.05 \times 10^{-12} \mathrm{~atm}$ 이며, 식(2)로부터 계산한 $\mathrm{Pb}$ 산화의 평형산소분압은 $4.02 \times 10^{-15} \mathrm{~atm}$ 으로 $\mathrm{Pb}$ 가 우선 적으로 산화되어야 할 것이다. 그러나 본 실험에서와 같 이 산소분압이 $0.2 \mathrm{~atm}$ 인 $\mathrm{N}_{2}+\mathrm{O}_{2}$ 혼합가스를 용탕 중 에 취입하는 경우 기포가 발생하고, 이 기포가 용탕 중 을 상승하는 동안 기포 표면에서 산화반응이 일어날 것 이다. 그리고 이러한 기포 주위의 산소분압은 상기한 $\mathrm{Bi}$ 와 $\mathrm{Pb}$ 의 평형산소분압보다 훨씬 높은 값을 나타내어 $\mathrm{Bi}$ 와 $\mathrm{Pb}$ 의 동시산화가 일어난 것으로 생각된다.

식(1)과 (2)를 조합하면 $\mathrm{Bi}$ 중 $\mathrm{Pb}$ 의 산화제거반응은 식(7)과 같이 나타낼 수 있다.

$$
2 \mathrm{Bi}+3 \mathrm{PbO}=\mathrm{Bi}_{2} \mathrm{O}_{3}+3 \mathrm{~Pb}
$$

그리고 식(7)의 평형상수는 식(8)과 같이 나타낼 수 있다.

$$
K_{(7)}=\frac{a_{\mathrm{Bi} 203} \cdot a_{\mathrm{Pb}}^{3}}{a_{\mathrm{PbO}}^{3} \cdot a_{\mathrm{Bi}}^{2}}=\frac{a_{\mathrm{Bi} 2 \mathrm{O} 3} \cdot\left(x_{\mathrm{Pb}} \cdot \gamma_{\mathrm{Pb}}\right)^{3}}{a_{\mathrm{PbO}}^{3} \cdot\left(x_{\mathrm{Bi}} \cdot \gamma_{\mathrm{Bi}}\right)^{2}}
$$

여기서 $a_{i}$ 는 $i$ 물질의 활동도를 나타내며, $x_{i}$ 는 몰분율, $\gamma_{i}$ 는 활동도 계수를 나타낸다. $923 \mathrm{~K}$ 에서 $K_{(7)}=2.38 \times 10^{-4}$ 이며, $1173 \mathrm{~K}$ 에서는 $K_{(7)}=4.31 \times 10^{-3}$ 으로 매우 낮은 값을 가진다. 따라서 산소에 의해서 $\mathrm{Bi}$ 가 산화되어도 식(7)의 역반응에 의해서 $\mathrm{Bi}_{2} \mathrm{O}_{3}$ 가 환원되고 $\mathrm{Pb}$ 가 산화 되어야 할 것이다.

식(9)에는 식(8)을 $\mathrm{Pb}$ 의 몰분율로 정리하여 나타내었다.

$$
x_{\mathrm{Pb}}=\left(\mathrm{K}_{(7)} \cdot \frac{a_{\mathrm{PbO}}^{3} \cdot \gamma_{\mathrm{Bi}}^{2}}{a_{\mathrm{Bi} 2 \mathrm{O} 3} \cdot \gamma_{\mathrm{Pb}}^{3}}\right)^{1 / 3} \cdot x_{\mathrm{Bi}}^{2 / 3}
$$

식(9)로부터 $\mathrm{Pb}$ 의 농도를 낮추기 위해서는 $K_{(7)}$ 과 $a_{\mathrm{PbO}}$ 는 낮아야 하며, $a_{\mathrm{Bi} 2 \mathrm{O} 3}$ 와 $\gamma_{\mathrm{Pb}}$ 는 커야 한다. 우선 $K_{(7)}$ 은 온도의 함수이며, 온도가 증가할수록 높은 값을 나타내므로 저온일수록 유리할 것으로 생각된다. 그리 고 $a_{\mathrm{Bi} 2 \mathrm{O} 3}$ 를 높이면 $\mathrm{Bi}$ 의 손실이 증가하므로, $a_{\mathrm{PbO}}$ 를 낮
추는 것이 유리할 것이다. Fruehan ${ }^{7)}$ 은 $1223 \mathrm{~K}$ 에서 $\mathrm{Bi}$ $\mathrm{Pb}$ 의 활동도에 대하여 보고하였으며, Yoon 등8)은 700 $\mathrm{K}$ 에서의 $\mathrm{Bi}-\mathrm{Pb}$ 의 활동도에 대하여 보고하였다. 온도에 따라 약간의 차이가 있으나 $\mathrm{Pb}$ 의 몰분율이 0.2 이하인 경우 $\mathrm{Pb}$ 의 활동도 계수 $\gamma_{\mathrm{Pb}}$ 는 약 $0.6, \gamma_{\mathrm{Bi}}$ 는 약 0.97 정도가 된다. 따라서 $\mathrm{Bi}-\mathrm{Pb}$ 합금 용탕을 산화시켜서 $\mathrm{Pb}$ 를 제거하기에는 불리한 조건이 되며, 효율적으로 $\mathrm{Pb}$ 를 산화제거하기 위해서는 염기성의 $\mathrm{PbO}$ 와 강한 결합에 의해 슬래그를 만들 수 있는 강산성 성분을 첨가하여 $a_{\mathrm{PbO}}$ 를 낮추는 것이 가장 유리할 것으로 생각된다.

\section{4. 결 론}

본 연구는 비철제련공정에서 발생하는 부산물을 환원 하여 회수한 $\mathrm{Bi}-\mathrm{Pb}-\mathrm{Sb}$ 합금 중에서 $\mathrm{Pb}$ 와 $\mathrm{Sb}$ 를 산화 제거하여 $\mathrm{Bi}$ 를 정제하기 위한 기초실험으로 수행되었으 며, 그 결과를 종합하면 다음과 같다.

1) $\mathrm{N}_{2}+\mathrm{O}_{2}$ 혼합가스 중의 산소분압이 증가함에 따라 $\mathrm{Sb}$ 의 휘발제거 속도가 증가하였으며, $\mathrm{Pb}$ 의 일부도 산화 되지만 산소가스 취입에 의해 $\mathrm{Sb}$ 만 산화물과 금속상의 혼합물로서 회수할 수 있다.

2) $\mathrm{Bi}-\mathrm{Pb}-\mathrm{Sb}$ 3원계에서 $\mathrm{Sb}$ 가 제거된 후와 $\mathrm{Bi}-\mathrm{Pb} 2$ 원계에 산소가스가 취입되면 $\mathrm{Pb}$ 가 산화되어 슬래그상 으로 제거되며, 가스유량이 증가함에 따라 $\mathrm{Pb}$ 의 산화속 도가 증가하지만, $\mathrm{Bi}$ 도 동시에 산화되어 전해정제에 제 공할 수 있는 순도 이상으로 $\mathrm{Bi}$ 를 정제할 수는 없다.

3) 열역학적으로 $\mathrm{Bi}-\mathrm{Pb} 2$ 원계 합금 용탕의 산화반응 에 의한 $\mathrm{Pb}$ 제거에 대하여 검토한 결과 염기성 슬래그 인 $\mathrm{PbO}$ 와 강한 결합을 할 수 있는 산성 슬래그인 $\mathrm{SiO}_{2}$ 등을 첨가하여 $a_{\mathrm{PbO}}$ 를 낮추는 것이 $\mathrm{Bi}$ 정제에 가 장 유리할 것으로 생각된다.

\section{참고문헌}

1. 吳在賢 등, 2012: 都市鑛山 再資源化기술의 모듈과 韓國 의 非鐵製鍊 프로세스, 資源리싸이클링, 21(1), pp. 3-16.

2. 井上洋, 天屋泰彥, 目時勝夫, 1989: 精銀工程の諸改善, 資 源・素材学会誌, 105(5), pp. 383-385.

3. 田村泰夫，南芳史，1993: 竹原製煉所の鉛製錚(三井金 属鉱業(株)), 資源・素材学会誌, 109(12), pp. 1029-1032.

4. John L. Bray, 1963: "Chapter 14 Lead" , Non-Ferrous Production Metallurgy $2^{\text {nd }} E d .$, p. 329, John Wiley \& Sons. Inc., New York, USA.

5. 阿座上竹四, 粟倉泰弘, 1999: “3.7 乾式精鍊”，金屬製鍊 
工學, p. 96, 日本金屬學會, 仙台, 일본.

6. Kubaschewski, O. and Alcock C. B., 1979: "Table D. Vaopur pressure and evaporation constants" , Metallurgical Thermochemistry $5^{\text {th }}$ Ed., p. 370-372, Pergamon Press, Oxford, U.K.

7. Fruehan, R. J., 1971: Mass Spectrometric Determination of

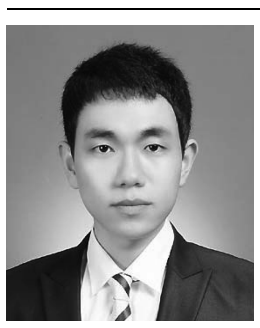

\section{金 世宗}

- 경북대학교 금속신소재공학과 학사

- 현대 경북대학교 대학원 금속신소 재공학과 재학

\section{孫 豪 祥}

- 현재 경북대학교 금속신소재공학과 교수

- 당학회지 제 11 권 6 호 참조
Activities for Alloys with Complex Vapor Species: $\mathrm{Bi}-\mathrm{Pb}$ and Bi-Tl, Metall. Trans., 2(4), pp. 1213-1218.

8. Yoon, S.W. and Lee, H. M., 1998: A Thermodynamic Study of Phase Equilibria in the Sn-Bi-Pb Solder System, Calphad, 22(2), pp. 167

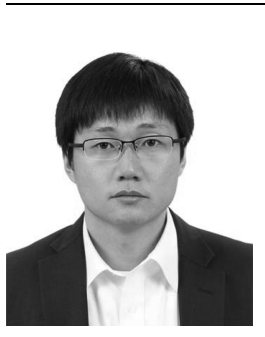

\section{孫 仁 俊}

- 경북대학교 금속공학과 학사

- 일본 Kyushu Univ. 석사(물질프로 세스공학)

- 일본 Kyushu Univ. 박사(물질프로 세스공학)

- 일본 N.E. CHEMCAT(주) 주임

- 현재 경북대학교 금속신소재공학과 교수 